\title{
Editorial: So, Philosophy Can Change Your Life?
}

It was, we suppose, inevitable. Tom Wolfe's A Man in Full ends with The Stoic's Hour on American network television. (See Philosophy, April 1999.) Fiction, of course, but Philosophy, a Guide to Happiness, presented by the author of How Proust Can Change Your Life is real and over here and on British television. Professional philosophers are reported to be snooty at what they see as shameless opportunism (or is it just they are annoyed that they didn't have the idea for themselves?).

So, can philosophy change your life? In one sense it obviously can, in the sense that anything can change your life, from tasting a madeleine and tripping over a flagstone (as in Proust) through a chance encounter on a train to reading, let us say, Seneca. The difference may be that whereas baking a madeleine was not done with the intention of changing anyone's life, let alone sparking off a 3,000 page novel, some philosophers have certainly intended that their work should change people's lives.

And philosophers have certainly succeeded in changing the lives of those who read them, and not just the obviously preacherly ones like Epicurus, Marcus Aurelius and Montaigne. Whole generations of young Germans fancied themselves as Nietzschean above the herd types. Russell inspired cohorts of free thinkers who all thought the same. And universities are full of people who reject the academic life in the spirit of Wittgenstein and of deconstructionists whose critiques of power structures have made them very powerful.

Yes, philosophy can change people's lives, but not necessarily in the way one might expect. 